\title{
Cancer testis antigen XAGE-1 is a promising marker for the diagnosis and treatment of ovarian cancer
}

\author{
Maysaa Ghazi Jumaa' ${ }^{\text {(DD }, ~ M u k h a l l a d ~ A b d u l-K a r e e m ~ R a m a d h a n ~}{ }^{2}$ (D) \\ Author Affiliations: \\ 1. Department of Microbiology, College of Medicine, University of Maisan, Maisan, Iraq \\ 2. Department of Pathology, College of Medicine, University of Maisan, Maisan, Iraq
}

\author{
* Corresponding Author: \\ Maysaa Ghazi Jumaa, \\ Bank Street, Auasha, Misan, Iraq. \\ Phone: +9647705575967; \\ E-mail: maisaagazi@yahoo.com \\ DOI \\ 10.25122/jml-2021-0304
}

Dates

Received: 30 August 2021

\begin{abstract} gens might be attractive targets for cancer detection and immunotherapy. Our work attempted to clarify the function played by cancer-testis antigens in ovarian cancers, notably in the XAGE1 gene. The investigation was conducted on 74 tissue samples from newly diagnosed patients with ovarian cancer. The control group included twenty-eight benign ovarian tumors. The expression of XAGE1 mRNA was assessed using RT-PCR. Compared to benign tumors, cancer samples exhibited higher levels of XAGE1 gene expression, which was statistically significant (P0.01). There were no statistically significant differences between menopausal status and family history. Gene expression was substantially connected with age groups as the higher level of gene expression in patients 50-74 years of age (P 0.01) was seen. Mucinous tumors exhibited significant correlations (P0.01) across histopathological tumor types. In correlation with tumor stages, stage III was substantially linked compared to stage I (P0.01). In conclusion, we referred to the potential to use XAGE1 to discriminate malignant ovarian tumors as a diagnostic biomarker. The connection of high XAGE 1 level with advanced ovarian cancer stages has also been established, supporting XAGE 1's proposed role in poor prognosis. Finally, finding the specific involvement of this gene in ovarian cancer and other kinds of malignancies may require further investigations.
\end{abstract}

KEYWORDS: XAGE1, ovarian cancer.

\author{
Accepted: 14 October 2021
}




\section{JOURNAL of MEDICINE and LIFE}

apoptosis avoidance [11]. The XAGE 1 gene is found on the X chromosome; it is strongly expressed in germ cells and is commonly seen in malignancies such as breast cancer, rhabdomyosarcoma, germ cell tumor, and Ewing's sarcoma [12]. XAGE 1 transcript variations include XAGE-1a, XAGE-1b, XAGE-1c, and XAGE-1d. These transcripts are expressed in various epithelial malignancies, including prostate, lung, and breast cancers, as well as Ewing sarcoma and metastatic melanoma [13]. The main transcript has been identified as XAGE-1b [14]. Previous research using SEREX analysis discovered that XAGE-1b might be involved in the production of antibody responses. CD4 and CD8 $\mathrm{T}$ cell responses against XAGE-1b in lung adenocarcinoma patients, leading to the hypothesis that XAGE-1b might be considered a potential antigen for tumor immunotherapy [15]. In this work, we looked at the expression of XAGE-1 in ovarian cancer tissues from Iraqi women to see if it had any diagnostic utility of XAGE-1 as a marker of ovarian cancer.

\section{MATERIAL AND METHODS}

Following total abdominal hysterectomy and bilateral salpingo-oophorectomy (TAH-BSO), subtotal abdominal hysterectomy, vaginal hysterectomy, and endometrial biopsy, 74 Paraffin-embedded tissue blocks from patients with various stages of newly diagnosed invasive ovarian cancer were provided by certain Iraqi hospitals. Twenty-eight (28) samples of benign ovarian tumor tissues were used as a control. In addition, patients' medical records were combed for information on their medical history and tumor characteristics. The paraffin-embedded tissue blocks were sectioned into 10m sections and placed in DNase-RNase tubes for molecular analysis. The samples were subjected to RNA extraction and molecular analysis using Reveres Transcription and Quantitative Real-Time PCR.

\section{RNA extraction}

Total RNA was extracted from ovarian cancer and benign tumor tissues using the RNeasy FFPE Kit (Qiagen-USA), which is intended for purifying total RNA from FFPE tissue sections, according to the manufacturer's procedure.

\section{Reverse transcription}

Thermo-ScriptTM Reverse Transcription kit (Invitrogen/USA) was used to reverse transcribe the whole RNA. The cDNA synthesis was carried out in a $50 \mu \mathrm{l}$ reaction volume. On the ice, all reaction mixtures were produced. $15 \mu \mathrm{l}$ of RNA was denaturized in a $0.5 \mathrm{ml}$ tube by incubation at $65^{\circ} \mathrm{C}$ for 5 minutes and then cooling on ice. The $5 \mathrm{x}$ cDNA synthesis buffers were vortexed for 5 seconds before use. Table 1 shows the master mixture components and their volumes. Each reaction tube received the master reaction mix. After that, the samples were put in a 96-well thermal cycler and cycled under the following conditions: 10 minutes at $25^{\circ} \mathrm{C}, 10$ minutes at $37^{\circ} \mathrm{C}$, 60 minutes at $42^{\circ} \mathrm{C}$, followed by 5 minutes at $75^{\circ} \mathrm{C}$. The converted cDNA was stored at $-80^{\circ} \mathrm{C}$ and then used as a template for PCR amplification. One of the housekeeping genes (PGK1) was used as a control gene.

\section{Constructs Synthesis}

The target gene's expression was confirmed using real-time quantitative qRT-PCR. To synthesize constructs for XAGE-1 and PGK1, qRT-PCR primers were developed to map the area of qRT-PCR amplification using cDNA from specific cancer patient samples with known expression for these genes, allowing us to manufacture constructs of the correct sizes.

\section{Real-time RT-PCR}

Primers were generated using the primer 3 plus program, and target and endogenous genes were sequenced using the primers given in Table 2. The Applied Biosystems 7900 equipment was used to run quantitative real-time PCR tests in triplicate. For quantitative evaluation, the Real-time PCR system primer and SYBR Green master mix were employed. The amplification process was carried out in a $20 \mu \mathrm{l}$ volume that contained $10 \mu \mathrm{l}$ of SYBR Green master mix, $1 \mu \mathrm{l}$ of primer mixes, $5 \mu \mathrm{l}$ of RNase free water, and $4 \mu \mathrm{l}$ of cDNA template. The Real-Time PGR methodology was as follows: stage $1: 50^{\circ} \mathrm{C}$ for 2 minutes, stage 2: $95^{\circ} \mathrm{C}$ for 10 minutes, stage 3: a two-step cycle process $\left(95^{\circ} \mathrm{C}\right.$ for 15 seconds and $65^{\circ} \mathrm{C}$ for 1 minute) repeated for 6 cycles, and stage 4 in a two-step cycle procedure $\left(95^{\circ} \mathrm{C}\right.$ for $15 \mathrm{sec}$. and annealing $61^{\circ} \mathrm{C}$ for $1 \mathrm{~min}$ ) repeated for 40 cycles.

\section{The estimation of gene expression}

The slope of a standard curve was used to calculate the efficiency of a real-time PCR reaction (E). The following formulae were used to calculate:

$$
\begin{aligned}
& \mathrm{E}=\left[10^{-1} / \text { slope }-1\right] \times 100 \\
& \mathrm{E}=\left[10^{-1} / 3.35-1\right] \times 100
\end{aligned}
$$




\section{JOURNAL of MEDICINE and LIFE}

Table 1. The reaction master mixture for cDNA preparation.

\begin{tabular}{|c|c|}
\hline Reagents & Volumes for $50 \mu \mathrm{l}$ \\
\hline Denaturized RNA & $15 \mu \mathrm{l}$ \\
\hline Random hexameter primers $3 \mu \mathrm{g} / \mu \mathrm{l}$ & $2.0 \mu \mathrm{l}$ \\
\hline 10 mM dNTP Mix & $5 \mu \mathrm{l}$ \\
\hline $5 x$ cDNA synthesis buffer & $10 \mu \mathrm{l}$ \\
\hline 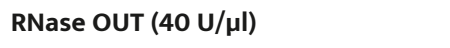 & $2.5 \mu \mathrm{l}$ \\
\hline Thermo Script RT (15 units/ $\mu \mathrm{l}$ ) & $2.5 \mu \mathrm{l}$ \\
\hline DEPC-treated water & $14.8 \mu \mathrm{l}$ \\
\hline Total & $50 \mu \mathrm{l}$ \\
\hline
\end{tabular}

Table 2. Primers sequences of target and endogenous genes.

\begin{tabular}{l|c}
\hline Primers & Sequence \\
\hline XAG1-CF & 5'-GGGCAGCAGACAGAAGAAGA-3' \\
\hline XAG1-CR & 5'-TTTGGTGAAAGCTGCAAAAC-3' \\
\hline PGK1-CF & 5'-GAGAAAGCCTGTGCCAACC-3' \\
\hline PGK1-CR & 5'-CTCCTACCATGGAGCTGTGG-3' \\
\hline XAGE1-F & 5'-GCGTCAAGGTGAAGATAATACCTAA-3' \\
\hline XAGE1-R & 5'-CATTTAAACTTGTGGTTGCTCTT-3' \\
\hline PGK1-F & 5'-GCGTCAAGGTGAAGATAATACCTAA-3' \\
\hline PGK1-R & 5'-CATTTAAACTTGTGGTTGCTCTT-3' \\
\hline
\end{tabular}

To compare across all samples, the Ct value is utilized. The Ct is proportional to the quantity of beginning mRNA of both the target gene (XAGE1) and the endogenous control gene (PGK1). The target gene's relative fold change ratio in the sample was determined as follows:

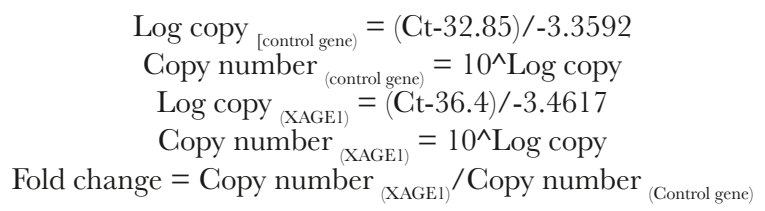

\section{Statistical Analysis}

The Statistical Analysis System - SAS application was used to determine the influence of different variables in research parameters [16]. To compare means, the least significant difference - the LSD test (Analysis of Variation-ANOVA) or the T-test- was used in this research.

\section{RESULTS}

The patients' ages ranged from 14 to 70 years, with a median of 47 years. According to the family history, all samples tested negative for an ovarian cancer family history. Table 3 lists the clinical characteristics of ovarian cancer samples. In terms of menopausal status, $34(46 \%)$ of ovarian cancer patients were premenopausal, whereas $40(54 \%)$ were postmenopausal. According to the International Federation of Gynecology and Obstetrics (FIGO) surgical staging method, the majority of samples (58.3\%) were classified as stage I, while the remaining $16(21.6 \%)$ were classified as stage III. According to the histological type, the samples were subdivided into serious tumors 32(43.24\%), clear cell tumors 4(5.4\%), clean tumors 4(5.4\%), germ cell tumors 4(5.4\%), and Burner $1(1,35 \%)$. In terms of malignancy status, ovarian cancer patients with XAGE1 positive gene expression had significantly higher levels of XAGE1 expression than benign tumor patients $(\mathrm{LSD}=2.319$, $\mathrm{p}$ value $=0.0001, \mathrm{P} 0.01$ ). Table 4 shows the relationship between XAGE1 gene expression and clinic-pathologic characteristics. The present study shows no statistically significant differences in gene expression levels with menopause and family history, while significantly associated with age groups since higher levels of gene expression in patients aged between 50-74 years $(\mathrm{LSD}=1.762, \mathrm{p}=0.0001, \mathrm{P} 0.01)$ were observed. The statistically significant differences in the level of expression of the XAGE1 gene compared to the other types of tumors in association with histopathological types $(\mathrm{LSD}=3,821, \mathrm{p}$ value $=0.0001, \mathrm{P} 0.01)$ were shown. In terms of tumor stages, levels of XAGE1 gene expression in stage III were substantially statistically different from levels of XAGE1 gene expression in stage I $(\mathrm{LSD}=1.948$, $\mathrm{p}$ value $=0.0001, \mathrm{P} 0.01)$.

\section{DISCUSSION}

The Cancer Genome Atlas (TCGA) has revealed driver mutations in ovarian carcinogenesis and novel techniques for targeted treatments [17]. However, only a few mutations in these mutation-driver genes may cause carcinogenesis [18-19]; among these genes, cancer-testis antigens (CTAs) or cancer-testis (CT) genes have piqued the interest of researchers due to their limited expression patterns 


\section{JOURNAL of MEDICINE and LIFE}

\begin{tabular}{l|c|}
\hline Age groups & $2(2.7 \%)$ \\
\hline Children (0-14 years) & $1(1.35 \%)$ \\
\hline Teenagers and young adults (15-24 years) & $28(37.83 \%)$ \\
\hline Adults (25-49 years) & $43(58.1 \%)$ \\
\hline Old age (50-74 years) & \\
\hline Menopause & $34(46 \%)$ \\
\hline Premenopausal no. (\%) & $40(54 \%)$ \\
\hline Postmenopausal no. (\%) & \\
\hline Family history & 0 \\
\hline Positive no. (\%) & $74(100 \%)$ \\
\hline Negative no. (\%) & \\
\hline FIGO stages & $18(24.32 \%)$ \\
\hline Stage I no. (\%) & $58(78.3 \%)$ \\
\hline Stage III no. (\%) & $16(21.6 \%)$ \\
\hline Histological type of tumor & $4(5.4 \%)$ \\
\hline Serous & $4(5.4 \%)$ \\
\hline Mucinous & $1.35 \%)$ \\
\hline Endometrioid & $32(43.24 \%)$ \\
\hline Germ cell tumor & \\
\hline Clear cell & \\
\hline Burner tumor & \\
\hline & \\
\hline
\end{tabular}

and immunogenicity [20]. Utilizing the qRT-PGR method, we investigated the feasibility of using the XAGE1 gene as a diagnostic and prognostic marker based on gene expression levels in ovarian carcinoma tissues. The current study found that XAGE1-positive ovarian cancer patients had considerably greater levels of XAGE1 gene expression than benign tumor patients, indicating that the XAGE1 gene has a high specificity as a diagnostic marker for distinguishing malignant from benign ovarian cancer. Our findings were consistent with a recent study that found elevation of XAGE $1 \mathrm{~b}$ mRNA expression in 64.4 percent of hepatocellular carcinoma tissue samples, but not in any benign liver tumors [21]. Gjerstorff et al. discovered significant levels of expression of numerous cancer-testis antigens (CTAs) in Tumorigenicity human mesenchymal stem cells, including XAGE-1 [22]. XAGE-1 expression profiles were comparable in lung cancer and immunogenic in patients [23]. Each of the GG genes (MAGEA1, NY-ESO1, and XAGE1) that James et al. assessed was not substantially expressed in benign prostate cell lines but was heterogeneously expressed in prostate cancer cell lines [24]. Sato et al. studied the prevalence of XAGE-1b mRNA among four alternative splicing variants, XAGE-la, b, c, and d, in lung cancer patients [25]. The identification of XAGE1 expression positivity based on family history and menopausal status revealed no significant connection, but XAGE $1 \mathrm{~b}$ mRNA was substantially higher in old patients aged 50-74 years than in other age groups. Previous research found that the expression of certain CT antigens was strongly related to the age, smoking history, and gender of lung cancer patients [26]. In 65.8 percent of patients with age -40 and $<60$, PAN et al. reported that elevated levels of XAGE $1 \mathrm{~b}$ mRNA had been reported, whereas other research revealed no significant correlation of age with CTA expressions, including XAGE 1 in non-small cell lung cancers [27]. Nakagawa et al. demonstrated no statistically important connection with XAGE-1b mRNA expression between the patients of age or sex [23]. Regarding the histological tumor types, statistically significant variations in gene expression levels of XAGE1 have been reported in the mucinous ovarian tumors compared to the others. The CT genes, including XAGE1, have been calculated in several ovarian tumor subtypes and stage heterogeneity, which have been clearly limited, making statistical calculations problematic. These findings showed the need for additional investigations of the CT gene with various features of ovarian cancers. The statistically significant difference in expression levels in connection to stage III has been shown compared with stage I. Similar results were found in earlier research, including Pan et al., who reported that XAGE $1 \mathrm{~b}$ mRNA levels were raised in patients with hepatocellular carcinoma 


\section{JOURNAL of MEDICINE and LIFE}

XAGE1 gene expression

\begin{tabular}{l|c}
\hline Tumor group & Mean \pm SE of XAGE1 gene \\
\hline Benign tumors & $0.254 \pm 0.06$ \\
\hline Malignant tumors & $10.89 \pm 0.77$ \\
\hline LSD Value (P-value) & $2.319^{* *}(0.0001]$ \\
\hline$* *(P \leq 0.01)$ & \\
\hline
\end{tabular}

** $(P \leq 0.01)$.

Age groups

Mean \pm SE of XAGE1 gene

children aged 0-14 years

$0.0178 \pm 0.0115$

Teenagers and young adults aged $15-24$ years

$0.00595 \pm 0.0022$

Adults aged 25-49 years

$0.8447 \pm 0.267$

Adults aged 50-74 years

$19.34 \pm 2.17$

LSD Value (P-value)

$1.762^{* *}(0.0001)$

** $(P \leq 0.01)$

\begin{tabular}{l|c|}
\hline Histological tumor type & Mean \pm SE of XAGE1 gene \\
\hline Mucinous & $49.44 \pm 4.52$ \\
\hline Serous & $0.7252 \pm 0.284$ \\
\hline Endometrioid & $0.0566 \pm 0.032$ \\
\hline Germ cell tumor & $0.0178 \pm 0.84$ \\
\hline Burner tumor & $0.0134 \pm 0.0094$ \\
\hline Clear cell & $0.00229 \pm 0.0016$ \\
\hline LSD Value (P-value) & $3.821 * *(00001)$ \\
\hline ** $(P \leq 0.01)$ & \\
\hline Tumor stage & Mean $\pm S E$ of XAGE1 gene \\
\hline Stage 1 & $0.01717 \pm 0.0085$ \\
\hline Stage 3 & $57.06 \pm 3.06$ \\
\hline LSD Value (P-value) & $1.948 * *(0.0001)$ \\
\hline$* *(P \leq 0.01)$ & \\
\hline
\end{tabular}

** $(\mathrm{P} \leq 0.01)$.

with higher stages of tumor node metastasis [II IV] [21]. Men et al. have discovered the pulmonary metastatic capacity of XAGE-1b in nude mice [28], but no association between CT expression and clinical variables like tumor history and histology has been observed in lung cancer patients [26]. Nakagawa et al. noted no association between the XAGE-1b mRNA expression or the lung cancer histologic level [23]. Our findings give further evidence of the potential involvement of XAGE 1 in invasive and metastatic cancer cells.

\section{CONCLUSION}

In conclusion, the present work has shown considerable variations in gene expression in the use of the XAGE1 gene for the diagnostic biomarker to discriminate between non-malignant ovarian cancers. The combination of elevated XAGE 1 level with advanced-stage ovarian cancer supports the idea that the gene may be a poor prognosis predictor. Overall, since the studies of the gene XAGE 1 in ovarian cancer are very few, the clinical and pathological traits of our patients were difficult to compare with previous studies. Further 


\section{JOURNAL of MEDICINE and LIFE}

studies are needed to detect the real role of this gene in ovarian cancer and to detect the gene's immunogenicity and the possibility of using it as an immunotherapy target.

\section{ACKNOWLEDGMENTS}

\section{Conflict of interest}

The authors declare that there is no conflict of interest.

\section{Ethics approval}

Procedures in this study were approved by the Bioethical Committee of Medical College - University of Misan (No. 152 in 2021).

\section{Consent to participate}

The consent of participation in the present study was taken from all patients from whom the samples were taken.

\section{Personal thanks}

The authors would like to acknowledge the staff pathology department in the Medical College-University of Misan for their assistance and advice, and technical support. Many thanks to the patients who agreed to use part of their samples to support the present study.

\section{Authorship}

MGJ developed the study conception, design, data analysis and draft manuscript preparation. MAKR performed the critical revision of the paper. MGJ supervised the research and complete funding acquisition. MGJ and MAKR gave final approval of the version to be published.

\section{REFERENCES}

1. Chen W, Zheng R, Baade PD, Zhang S, Zeng H, Bray F, Jemal A, Yu XQ, He J. Cancer statistics in China, 2015. CA Cancer J Clin. 2016 Mar-Apr;66(2):115-32

2. Testa U, Petrucci E, Pasquini L, Castelli G and Pelosi E. Ovarian Cancers: Genetic Abnormalities, Tumor Heterogeneity and Progression, Clonal Evolution and Cancer Stem Cells. Medicines. 2018; 5(16).

3. Siegel RL, Miller KD, Jemal A. Cancer statistics. CA Cancer J Clin. 2016;66(1):7-30.

4. Zhao S, Bellone S, Lopez S, Thakral D, Schwab C, English DP, Black J, Cocco E, Choi J, Zammataro L, Predolini F Bonazzoli E, Bi M, Buza N, Hui P, Wong S, Abu-Khalaf M, Ravaggi A, Bignotti E, Bandiera E, Romani C, Todeschini P, Tassi R, Zanotti L, Odicino F, Pecorelli S, Donzelli C, Ardighieri L, Facchetti F, Falchetti M, Silasi DA, Ratner E, Azodi M, Schwartz PE, Mane S, Angioli R, Terranova C, Quick CM, Edraki B, Bilgüvar K, Lee M, Choi M, Stiegler AL, Boggon TJ, Schlessinger J, Lifton RP, Santin AD. Mutational landscape of uterine and ovarian carcinosarcoma implicates histone genes in epithelial-mesenchymal transition. Proc Natl AcadSci U S A. 2016 Oct 25;113(43):12238-12243.

5. Kandoth C, McLellan MD, Vandin F, Ye K, Niu B, Lu C, Xie M, Zhang Q,McMichael JF, Wyczalkowski MA, Leiserson MDM, Miller Ca, Welch JS, Walter MJ, Wendl MC, Ley TJ, Wilson RK, Raphael BJ, Ding L.Mutational landscape and significance across 12 major cancer types. Nature. 2013; 502(7471):333-9

6. Vogelstein B, Papadopoulos N, Velculescu VE, Zhou S, Diaz LA Jr, Kinzler KW. Cancer genome landscapes. Science. 2013 Mar 29;339(6127):1546-58.

7. Ali MA, Sjöblom T. Molecular pathways in tumor progression: from discovery to functional understanding MolBiosyst. 2009 Sep;5(9):902-8. doi: 10.1039/b903502h. Epub 2009 Jul 14. PMID: 19668850

8. Jordan EJ, Radhakrishnan R. Machine Learning Predictions of Cancer Driver Mutations.Proc $20146^{\text {th }}$ IntAdv Res Worksop In Silico Oncol Cancer Investig (2014). 2014 Nov; doi: 10.1109/iarwisoci.2014.7034632.PMID: 34622251.

9. Wang C, Gu Y, Zhang K, Xie K, Zhu M, Dai N, Jiang Y, Guo X, Liu M, Dai J, Wu L, Jin G, Ma H, Jiang T, Yin R, Xia Y, Liu L, Wang S, Shen B, Huo R, Wang Q. Xu L, Yang L, Huang X, Shen H, Sha J, Hu Z. Systematic identification of genes with a cancer-testis expression pattern in 19 cancer types. Nat Commun. 2016 Jan 27; 7:10499.

10. Simpson AJ, Caballero OL, Jungbluth A, Chen YT, Old LJ. Cancer testis antigens, gametogenesis and cancer. Nat Rev Cancer. 2005;5(8):615-25.

11. Scanlan MJ, Simpson AJG, Old LJ. The cancer/testis genes: review, standardization, and commentary. Genes: review, standardization,

12. Mahmoud AM. Cancer testis antigens as immunogenic and oncogenic targets in breast cancer. Immunotherapy 2018 Jul; 10(9):769-778. doi: 10.2217/imt-2017-0179.

13. Brinkmann U, Vasmatzis G, Lee B, Pastan I. Novel genes in the PAGE and GAGE family of tumor antigens found by homology walking in the dbEST database. Cancer Res. 1999; 59: 14451448.

14. Egland KA, KumarV, DurayP, Pastan I. Characterizatio of overlapping XAGE-1 transcripts encoding a cancer testis antigen expressed in lung, breast, and other types of cancers. MolCancerTher. 2002; 1:441-50

15. Zendman AJ, Van Kraats AA, Weidle UH, Ruiter DJ, Van Muijen GN. The XAGE family of

cancer/testis-associated genes: alignment and expression profile in normal tissues, melanoma lesions and Ewing's sarcoma. Int J Cancer. 2002;99(3):361-9.

16. SAS. Statistical Analysis System, User's Guide. Statistical. Version $9.1^{\text {th }}$ ed. SAS. Inst. Inc. Cary. N.C. USA. 2012

17. Dong F, Davineni PK, Howitt BE, Beck AH. A BRCA1/2 Mutational Signature and Survival in Ovarian High-Grade Serous Carcinoma. Cancer Epidemiol Biomarkers Prev 2016;25(11):1511-6.

18. Kandoth C, McLellan MD, Vandin F, Ye K, Niu B, Lu C,Xie M, Zhang Q, McMichael JF, WyczalkowskiMA Leiserson MDM, Miller CA, Welch JS, Walter MJ, Wend MC, Ley Tj, Wilson RK, Raphael BJ, Ding L. Mutationa landscape and significance across 12 major cancer types. Nature. 2013; 502(7471):333-9.

19. Vogelstein B, Papadopoulos N, Velculescu VE, Zhou S, Diaz LA Jr, Kinzler KW. Cancer genome landscapes. Science. 2013;339(6127):1546-58

20. Wang C, Gu Y, Zhang K, Xie K, Zhu M, Dai N, Jiang Y, Guo X, Liu M, Dai J, Wu L, Jin G, Ma H, Jiang T, Yin R,
Xia Y, Liu L, Wang S, Shen B, Huo R, Wang Q, Xu L, Yang L, Huang X, Shen H, Sha J, Hu Z. Systematic identification of genes with a cancer-testis expression pattern in 19 cancer types. Nat Commun. 2016 Jan 27; 7:10499.

21. Pan Z, Tang B,Hou Z, Zhang J, Liu H, Yang Y, Huang G, Yang $\mathrm{Y}$, Zhou W. XAGE 1b expression is associated with the diagnosis and early recurrence of hepatocellular carcinoma Molecular and Clinical Oncology 2. 2014; 1155-1159.

22. Gjerstorff M, Burns JS, Nielsen O, Kassem M, Ditzel $\mathrm{H}$. Epigenetic modulation of cancer-germline antigen gene expression in Tumorigenicity human mesenchymal stem cells: implications for cancer therapy.Am J Pathol. 2009; 175:314-23.

23. Nakagawa K, Noguchi Y, Uenaka A, Sato S, Okumura H, Tanaka M, Shimono M, Mohamed AE, Ohara N, Yoshino T, Yamashita K, Tsunoda T, Aoe M, Shimizu N, Nakayama E. XAGE-1Expression in NonSmall Cell Lung Cancer and Antibody Response in Patients Clin Cancer Res. 2005; 11(15).

24. James SR, Cedeno CD, Sharma A, Zhang W, Mohler JL, Odunsi K, Wilson EM, Karpf AR. DNA methylation and nucleosome occupancy regulate the cancer germline antigen gene MAGEA11.Epigenetics. 2013; 8: 849-863

25. Sato S, Noguchi Y, Ohara N, Uenaka A, Shimono M, Nakagawa K, Koizumi F, Ishida T, Yoshino T, Shiratori Y, Nakayama E. Identification of XAGE-1 isoforms: predominant expression of XAGE-1b in testis and tumors. Cancer Immunity. 2007; 7: 5

26. Kim Y, Park H, Song M, Shin D, Lee C, Lee M, Lee S. Pattern of cancer testis antigen expression in lung cancer patients. International Journal of Molecular Medicine. 2012; 29: 656-662

27. Jin S, Cao S, Grigorev A, Meng Q, Wang Ch, Feng $\mathrm{M}$, Jing H, Jiang F, Yu Y. Establishment of cancer/testis antigen profiling based on clinicopathological characteristic in resected pathological stage iii non-small cell lung cancer: Cancer Management and Research. 2018; 10.

28. Men H, Zhang Z, Lu G, Tan Sh, Hu W, Yang X, Geng F XAGE-1b Promotes the Proliferation, Invasion and Metastasis of Gastric Cancer. Research Square. 2020; 1-15. 